\title{
Isolation of Antibiotic Producing Actinomycetes from Saltpans
}

\author{
Gajula Swarna Kumari, Prasada Babu Gundala and Paramageetham Chinthala* \\ Department of Microbiology, Sri Venkateswara University, Tirupati- 517502, \\ Andhra Pradesh, India \\ *Corresponding author
}

\section{Keywords}

Actinomycetes, Screening,

Antibacterial activity, Agar well diffusion

Article Info

Accepted:

12 March 2021

Available Online:

10 April 2021

\section{A B S T R A C T}

Actinobacteria was an important origin of novel bioactive metabolites with significant pharmaceutical applications. A total of 22 isolates were isolated from the salt pan soils and studied their cultural, physiological characteristics. Finally, they were subjected to the screening for antibiotic producing actinomycetes by agar well diffusion assay against two gram positive (Bacillus subtilis, Staphylococcus aureus) and two gram negative bacteria (Escherichia coli, Klebsiella pneumoniae). Among the tested, two groups of gram positive bacteria were more sensitive and inhibited by 17 isolates $(81.8 \%)$ and gram negative bacteria were less sensitive and inhibited by 11 isolates (50\%). However, both gram+ve and gram-ve bacteria were inhibited by 6 isolates $(27 \%)$.

\section{Introduction}

Actinomycetes are the most extensively assigned group of microorganisms in nature which mainly inhabit the soil (Oskay et al., 2004). Approximately $80 \%$ of the world's antibiotics are well-known to come from Actinomycetes, mostly from the genera Streptomyces and Micromonospora (Pandey et al., 2004). Actinobacteria are a best source of various bioactive compounds they are antibiotics, pesticides, enzymes, immune modulators, herbicides, anti-infective and anticancer agents(Newman and Cragg2007,
Takahashi andomura, 2003). Streptomyces are the largest genus of Actinobacteria proposed by Waksman and Henrici in 1943. They are Gram positive, aerobic, spore forming filamentous bacteria (Abussaud et al., 2013). They produce an extensive branching substrate mycelium that are tough, leathery and produce diffusible pigments (Euzeby, 2008). Their aerial mycelium bears chains of arthrospores. Development of antibiotic resistance microbes to the commonly available antibiotics and antifungal agents has necessitated the requirement of new compounds and the members of the genus 
Streptomyces offers promising lead compounds (Jayapradha Ramakrishnan, 2009).Traditional screening methods have led to the isolation of common microorganisms capable of producing metabolites, which have already been extensively studied and established (Okami and Hotta 1988; Kurtboke et al., 1992). Among the current strategies of natural-product screening, improved methodologies for isolating the uncommon and less studied rare actinomycetes are required to avoid the repeated isolation of the strains that produce known bioactive metabolites, and to improve the quality of the screened natural products (Takahashi and Omura 2003;Berdy 2005; singhet al., 2009). The metabolites produced by halophiles like ectoine, betaine, carotenoid pigments, enzymes, anticancer and antibacterial compounds have immense applications in pharmacy and biomedicine (Thombre and Oke, 2016). Marine sediment, soil, water, contaminated regions on the seashore, salt lakes, saline soils, alkaline-saline habitats, brines, and other regions are good sources for the selection of novel halophilicactinomycetes. The present investigation was undertaken to isolate, characterize and screen the actinomycetes from salt pan sediment soils.

\section{Materials and Methods}

\section{Collection of soil samples}

The soil samples were collected using randomised block design at a depth of $6-10 \mathrm{~cm}$ saltpan sediments situated at Nellore district of Andhra Pradesh $\left(14^{\circ} 44^{1} 33.6^{\circ} \mathrm{N}-80^{\circ} 06^{1} 17.7^{\circ} \mathrm{E}\right)$. The collected samples were stored at $4^{0} \mathrm{C}$ in sterile polythene bags.

\section{Isolation of actinomycetes}

Actinomycetes were isolated using standard dilution plate technique(Rahman et al., 2010).
Using Glycerol asparagine agar, yeast extract and malt extract Agar media (Downes andIto 2001), starch casein agar medium's (Kuster and Williams 1964) containing nystatin $(50 \mu \mathrm{g} / \mathrm{ml})$.The Prepared plates were incubated at $28^{0} \mathrm{C}$ for 7 days. Pure cultures were obtained after repeated subcultures and maintained as spore suspension in $20 \%(\mathrm{v} / \mathrm{v})$ glycerol at $-20^{\circ} \mathrm{C}$ or further use.

\section{Cultural and physiological characteristics of actinomycetes}

Cultural charcteristics of the isolates were studied according to the Shirling and Gottlieb(1966) based on their growth of the colony, colour of the aerial mycelium and substrate mycelium, pigmentation (Macroscopically) and also Physiological conditions like Temperature, $\mathrm{pH}$ and $\mathrm{NaCl}$ concentrations were observed for halophilic actinomycete isolates (SVNMA1, SVNMA2, SVNMA3, SVNMA4, SVNMA5, SVNMA6, SVNMA7, SVNMA8, SVNMA9, SVNMA10, SVNMA11, SVNMA12, SVNMA13, SVNMA14, SVNMA15, SVNMA16, SVNMA17, SVNMA18, SVNMA19, SVNMA20, SVNMA21 and SVNMA22).

\section{Screening of actinomycetes for antibiotics}

The clinical isolates namely Bacillus subtilis, Staphylococcus aureus, Escherichia coli and Klebsiella pneumoniae were procured from Sri Venkateswara Ramnarain Ruia Government General Hospital, (Ruia Hospital) Tirupati. Nutrient agar and nutrient broth were used for routine culturing. A total of 22 actinomycete isolates were subjected to submerged fermentation technique (Atta and Ahmad 2009). They were inoculated in 1.0 litre flask containing $600 \mathrm{ml}$ yeast extract and malt extract broth and incubated on rotary shaker (120rpm) at $30^{\circ} \mathrm{C}$ for 7 days. Fermeted broth was filtered through Whatman no.1 filter paper and then centrifuged at $5000 \mathrm{rpm}$ for 20 
min and supernatants were tested for antibacterial activity by agar well diffusion method (Baker et al.,1991). Different concentrations of supernatants $(50 \mu 1,100 \mu 1$, $150 \mu \mathrm{l}$ and $200 \mu \mathrm{l}$ ) were placed into the wells they were previously seeded with bacterial pathogens; they are gram positive bacteria (Bacillus subtilis and Staphylococcus aureus) and gram-negative bacteria (Escherichia coli and Klebsiella pneumoniae). The plates were incubated at $30^{\circ} \mathrm{C}$ for 48 hours and the zone of inhibition was measured. All the tests were done in triplicates.

\section{Results and Discussion}

\section{Isolation of antibiotic producing actinomycetes}

Various media and methods were employed for the isolation of actinomycetes from solar saltpan soils. In order to standardize the isolation procedure few preliminary investigations such of media type, pour plate and spread plate techniques were compared.

Three different types of media namely Glycerol asparagine (ISP-5), Yeast extract and malt extract agar medium (ISP-2) and Starch casein agar medium were tested to support the growth of large number of colonies from marine sediments. Among the three media tested, ISP-2 consistent in all dilutions supported higher number of colonies (Table1). Therefore ISP-2 media was selected for preliminary routine work.

Both pour plate method and spread plate methods were evaluated for this suitability for isolation of antibiotics. Among the two tested methods distinct colonies were appeared in pour plate method. In spread plate method due to high colony number distinct colonies are less. Therefore, pour plate method was employed for isolation of actinomycetes (Table-2). Isolation of actinomycetes is the first and the most important step of actinomycetes resource development. The primary aim of such investigations has been to develop the most rapid and accurate method for proving the novelty of newly isolated strains (Hain et al., 2007). Isolation and Screening of actinomycetes be going to choose a useful medium in extension tochoice of major ecological environment as the division of outside sources. Various media and methods were employed for the isolation of actinomycetes, in order to standardize the isolation procedure few preliminary investigations such of media type, pour plate and spread plate techniques were compared. Three different types of media namely Glycerol asparagine (ISP-5), Yeast extract and Malt extract agar medium (ISP-2) and Starch casein agar medium.

\section{Pure Cultures of Actinomycetes}

The colony growth in most of the isolates was scanty (SVNMA1, SVNMA3-4, SVNMA6, SVNMA9-11, SVNMA13-19). Four isolates exhibited moderate growth (SVNMA2, SVNMA7, and SVNMA8) and a single isolate (SVNMA12) exhibited abundant growth.

All pure cultures were maintained on ISP-2 medium (Plate-1,2,3\&4). In case of aerial mass of the colonies ranged from whitish ash to dark ash, light brown to dark brown, light pink to dark pink. Riverside pigmentation and soluble pigments were not detected in most of the isolates except SVNMA2, SVNMA3 and SVNMA13.

Similarly, melanoid pigmentation was absent in all the isolates except SVNMA13.The cultural characteristics of antibiotic producing actinomycetes were presented in Table-3.In all 22 isolates, some isolates exhibited the optimum growth at $30^{\circ} \mathrm{C}$ and some isolates exhibited the optimum growth at $40^{\circ} \mathrm{C}$. When compared to $10^{\circ} \mathrm{C}, 20^{\circ} \mathrm{C}$ and $50^{\circ} \mathrm{C}($ Fig- 1$)$. 
Table.1 Colony Forming Units (CFU) of actinomycetes on various media

\begin{tabular}{|c|c|c|c|c|}
\hline Name of the media & \multicolumn{3}{|c|}{ Colony Forming Units (CFU) ml/g sediment } \\
\hline Dilutions & $10^{-1}$ & $10^{-2}$ & $10^{-3}$ & $10^{-4}$ \\
\hline $\begin{array}{c}\text { Glycerol asparagine agar medium } \\
\text { (ISP-5) }\end{array}$ & $1.4 \times 10^{1}$ & $1.2 \times 10^{2}$ & $1.0 \times 10^{3}$ & $0.7 \times 10^{4}$ \\
\hline $\begin{array}{c}\text { Yeast extract and malt extract agar } \\
\text { medium (ISP-2) }\end{array}$ & $1.9 \times 10^{1}$ & $1.4 \times 10^{2}$ & $1.4 \times 10^{3}$ & $1.2 \times 10^{4}$ \\
\hline Starch Casein Agar & $1.0 \times 10^{1}$ & $0.9 \times 10^{2}$ & $0.5 \times 10^{3}$ & $0.4 \times 10^{4}$ \\
\hline
\end{tabular}

Table.2 Pour Vs Spread plate methods in Yeast extract and malt extract agar media

\begin{tabular}{|c|c|c|}
\hline Dilutions & Pour plate & Spread plate \\
\hline $\mathbf{1 0}^{-1}$ & $1.9 \times 10^{1}$ & $6.8 \times 10^{1}$ \\
\hline $\mathbf{1 0}^{-2}$ & $1.4 \times 10^{2}$ & $5.1 \times 10^{2}$ \\
\hline $\mathbf{1 0}^{-3}$ & $1.4 \times 10^{3}$ & $2.6 \times 10^{3}$ \\
\hline $\mathbf{1 0}^{-4}$ & $1.2 \times 10^{4}$ & $1.1 \times 10^{4}$ \\
\hline
\end{tabular}

Table.3 Cultural and physiological characteristics ofactinomycete isolates

\begin{tabular}{|c|c|c|c|c|c|c|}
\hline $\begin{array}{l}\text { Name of the } \\
\text { isolate }\end{array}$ & $\begin{array}{l}\text { Growth } \\
\text { of the } \\
\text { colony }\end{array}$ & $\begin{array}{c}\text { Aerial } \\
\text { mass/Colour of } \\
\text { the colony }\end{array}$ & $\begin{array}{l}\text { Substrate } \\
\text { mycelium } \\
\text { colour }\end{array}$ & $\begin{array}{c}\text { Reverse side } \\
\text { pigmentation* }\end{array}$ & $\begin{array}{c}\text { Melanoid } \\
\text { pigmentation* }\end{array}$ & $\begin{array}{l}\text { Soluble } \\
\text { pigment* }\end{array}$ \\
\hline SVNMA 1 & Scanty & Ash & Ash & ND & ND & ND \\
\hline SVNMA 2 & Moderate & $\begin{array}{l}\text { Brownish } \\
\text { yellow }\end{array}$ & Whitish ash & Light brown & ND & $\begin{array}{l}\text { Light } \\
\text { brown }\end{array}$ \\
\hline SVNMA 3 & Scanty & Ash & $\begin{array}{l}\text { Light ash } \\
\text { yellow }\end{array}$ & Yellow & ND & $\begin{array}{l}\text { Light } \\
\text { yellow }\end{array}$ \\
\hline SVNMA 4 & Scanty & Creamy & Creamy & ND & ND & ND \\
\hline SVNMA 5 & Abundant & Dark green & Green & ND & ND & ND \\
\hline SVNMA 6 & Scanty & Ash & Whitish ash & ND & ND & ND \\
\hline SVNMA 7 & Moderate & Yellowish & Pale yellow & ND & ND & ND \\
\hline SVNMA 8 & Moderate & Light white & Pale yellow & ND & ND & ND \\
\hline SVNMA 9 & Scanty & Creamy & Light pink & ND & ND & ND \\
\hline SVNMA 10 & Scanty & Pale ash & Ash & ND & ND & ND \\
\hline SVNMA 11 & Scanty & Whitish & Whitish & ND & ND & ND \\
\hline SVNMA 12 & Moderate & Pink & Light brown & ND & ND & ND \\
\hline SVNMA 13 & Scanty & Ash & Dark brown & Brown & Brown & $\begin{array}{l}\text { Light } \\
\text { black }\end{array}$ \\
\hline SVNMA 14 & Scanty & Brownish cream & Light pink & ND & ND & ND \\
\hline SVNMA 15 & Scanty & Dark ash & Dark ash & ND & ND & ND \\
\hline SVNMA 16 & Scanty & Creamy & Creamy & ND & ND & ND \\
\hline SVNMA 17 & Scanty & Dark creamy & $\begin{array}{l}\text { Dark } \\
\text { creamy }\end{array}$ & ND & ND & ND \\
\hline SVNMA 18 & Scanty & Ash & Ash & ND & ND & ND \\
\hline SVNMA 19 & Scanty & Creamy & Dark pink & ND & ND & ND \\
\hline SVNMA 20 & Scanty & Pink & Cream & ND & ND & ND \\
\hline SVNMA 21 & Scanty & Light yellow & Whitish & ND & ND & ND \\
\hline SVNMA 22 & Scanty & Dark brown & Brownish & Dark green & ND & ND \\
\hline
\end{tabular}

*ND Not detected 
Table.4 Screening of selected antibiotic producing actinomycetes (SVNMA1-SVNMA22) for antibacterial activity

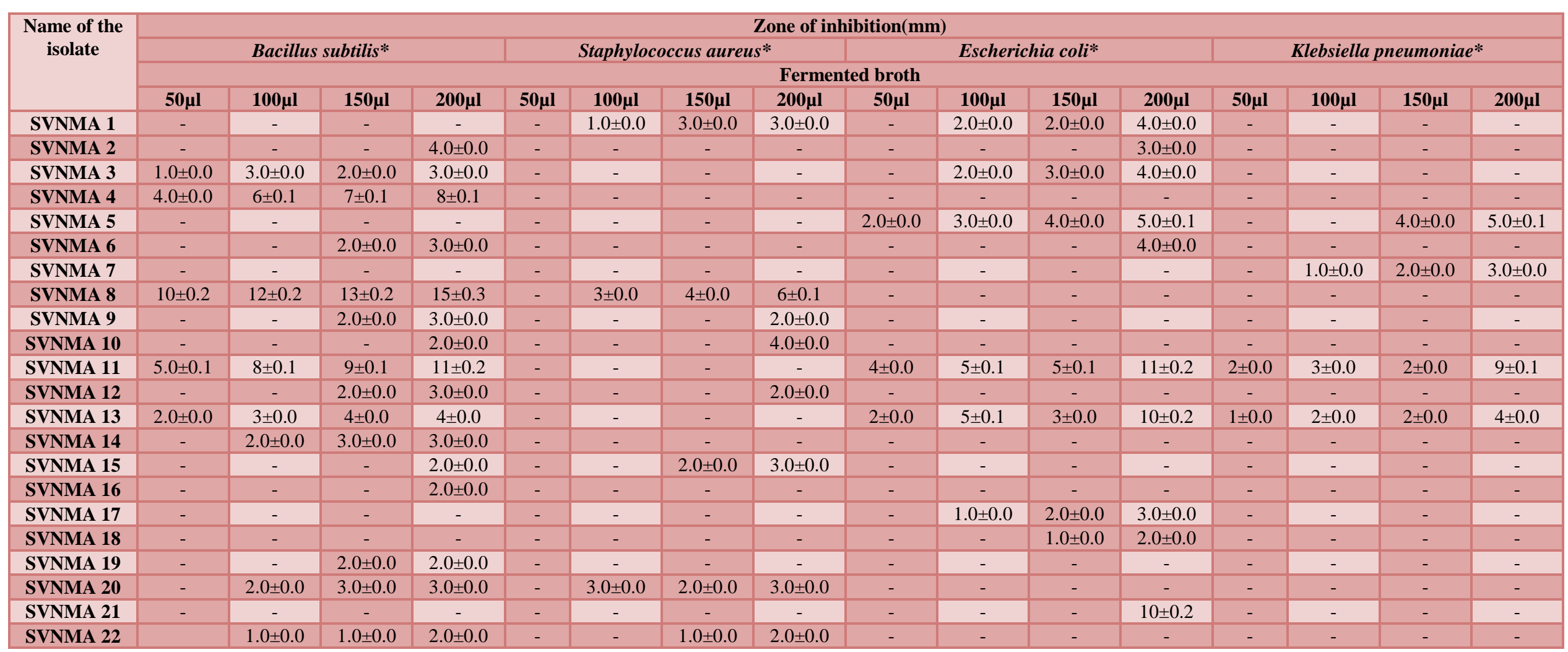

The values are the Means \pm S.E for the experiments, *- no zone of inhibition 
Plate.1 Pure cultures of actinomycete isolates (SVNMA1-SVNMA6)
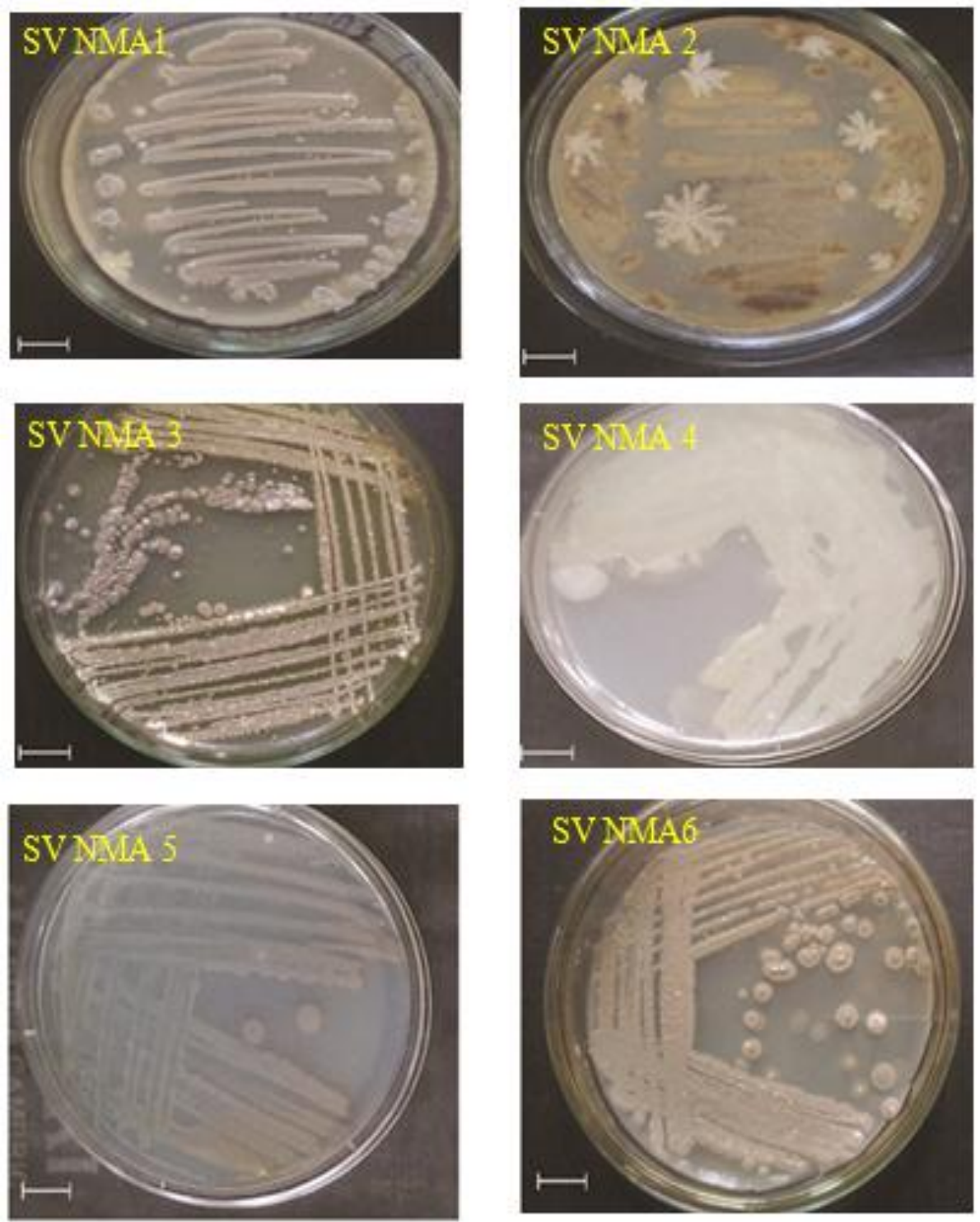
Plate.2 Pure cultures of actinomycete isolates (SVNMA7-SVNMA12)
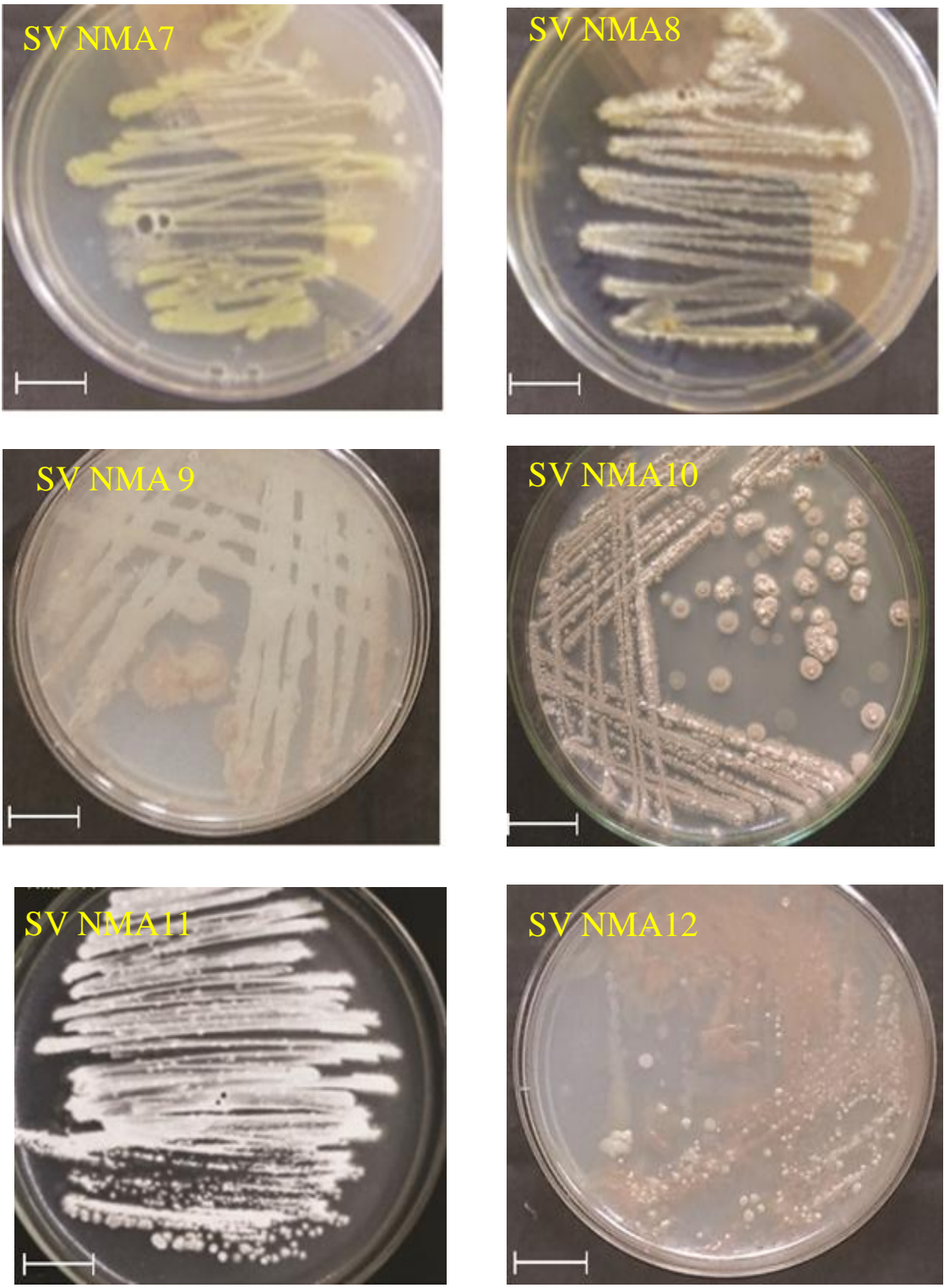
Plate.3 Pure cultures of actinomycete isolates (SV NMA13-SVNMA18)
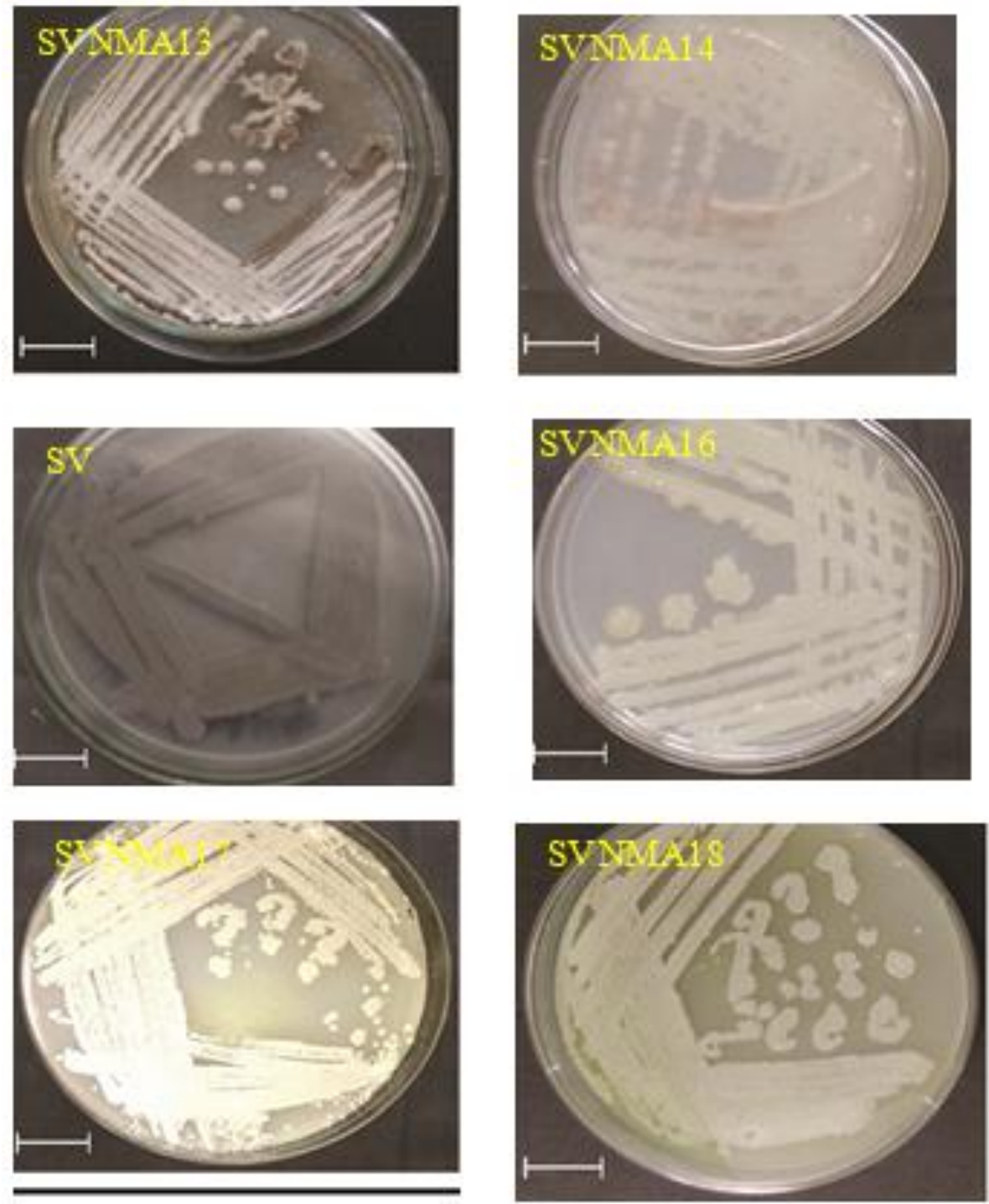
Plate.4 Pure cultures of actinomycete isolates (SV NMA19-SVNMA22)
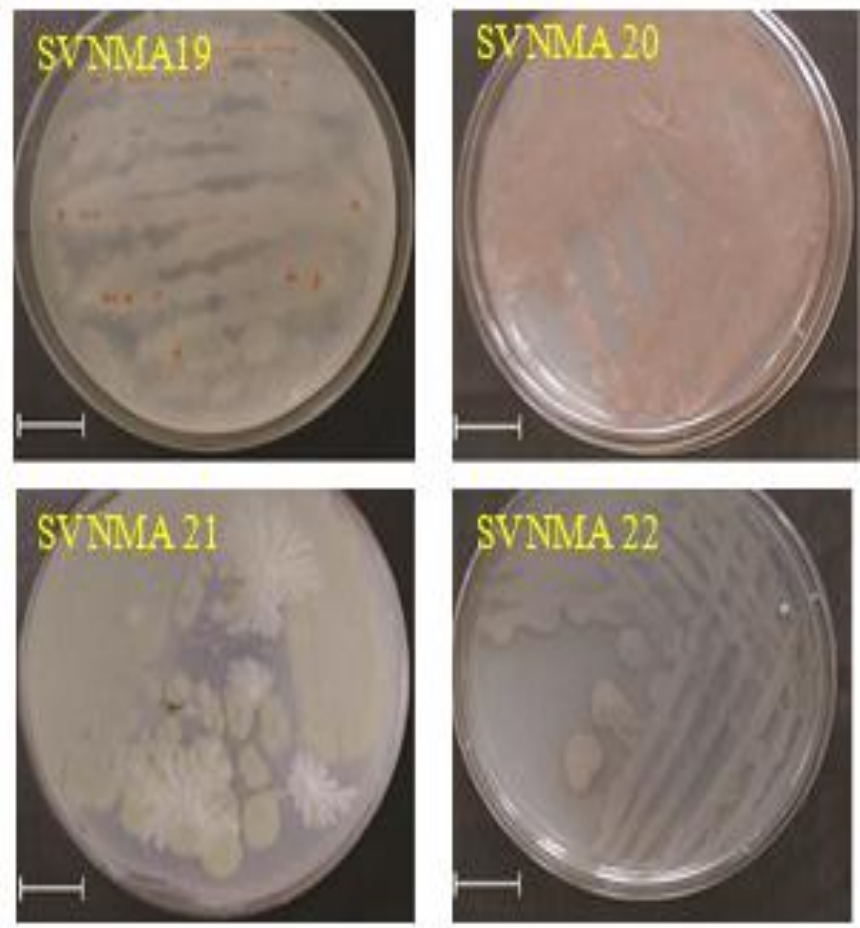

Fig.1 Effect of temperature on growth of actinomycete isolates

\section{Temnerature}

1.

0.

$10^{\circ} \mathrm{C} \quad 20^{\circ} \mathrm{C} \quad 30^{\circ} \mathrm{C} \quad 40^{\circ} \mathrm{C} \quad 50^{\circ} \mathrm{C}$ 
Fig.2 Effect of $\mathrm{pH}$ on growth of actinomycete isolates

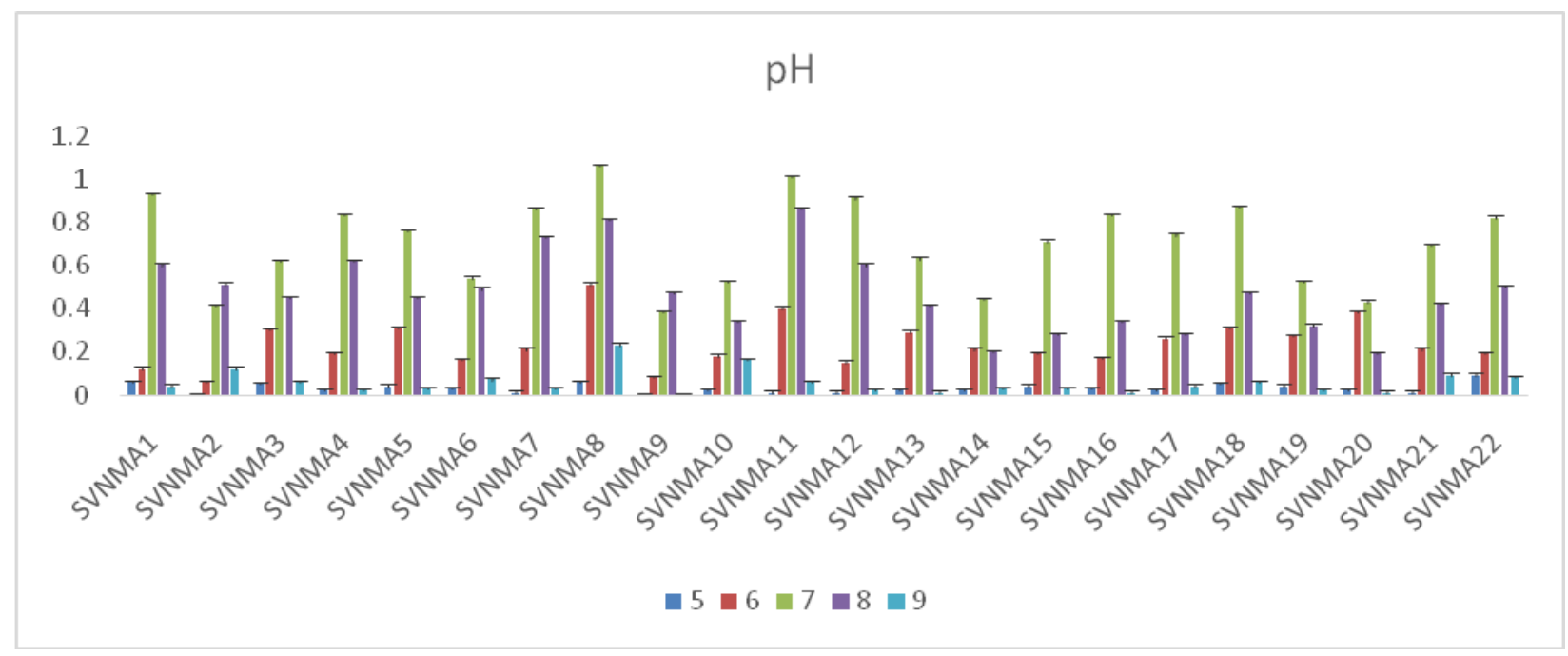

Fig.3 Effect of $\mathrm{NaCl}$ concentrations on growth of actinomycete isolates

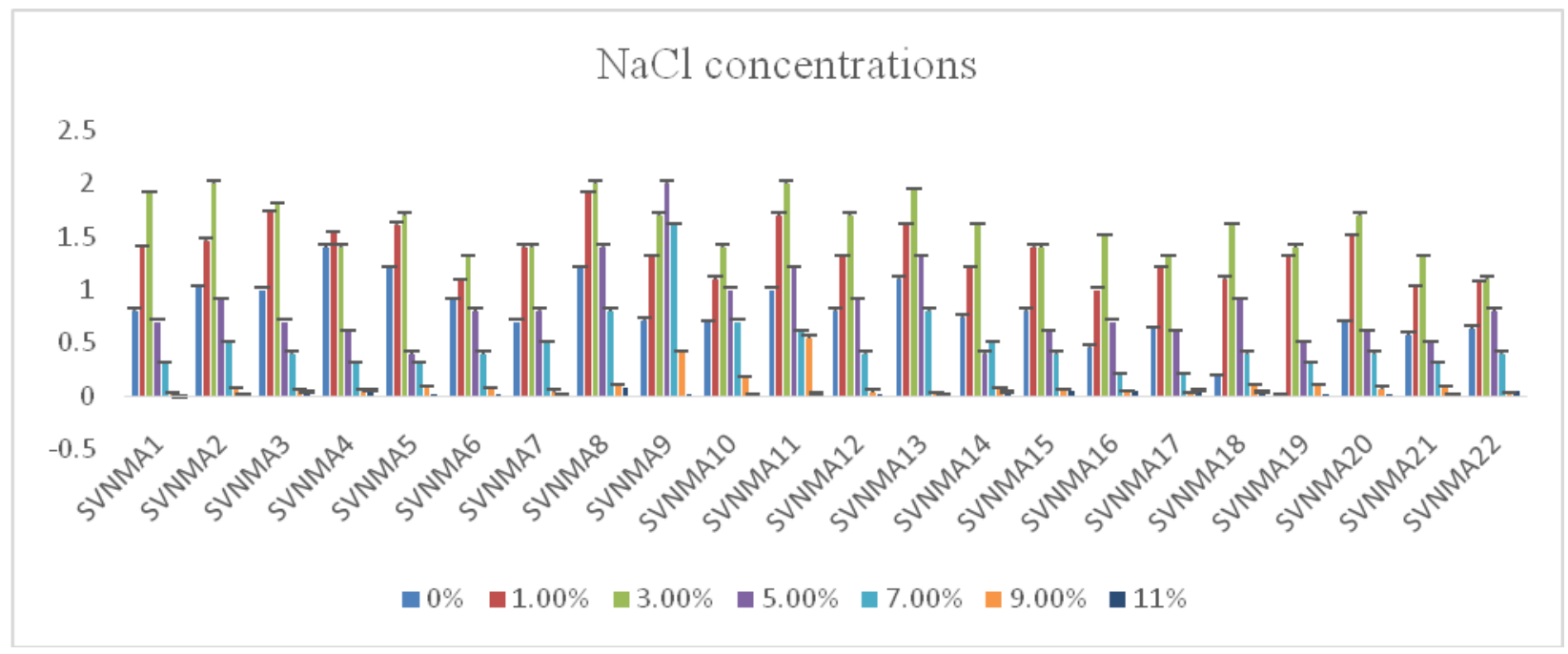

In case of $\mathrm{pH}$ some isolates exhibited the optimum growth at $\mathrm{pH} 7.0$ and some isolates exhibited the optimum growth at $\mathrm{pH} 8.0$ also (Fig-2).In case of $\mathrm{NaCl}$ concentrations some isolates exhibited the optimum growth at $3.0 \%$ and some isolates exhibited the optimum growth at $1.0 \%$ also (Fig-3). Streptomyces spp. VITSVK 9 showed the maximum growth with highest biomass at $30^{\circ} \mathrm{C}$ and at $5 \%$ of $\mathrm{NaCl}$ concentration in the medium and at $\mathrm{pH}$ 7.0; and the growth of the strain was inhibited in the absence of $\mathrm{NaCl}$ in the medium (Sauravand Kannabiran, 2010).A strain of
Streptomyces grancidicus with optimum activity at $40^{\circ} \mathrm{C}, \mathrm{pH}-7.0$ and $1.5 \% \mathrm{NaCl}$ has been reported in 2015 from Indian soil (Krishnan and Kumar, 2015).

Screening of selected antibiotic producing halophilic actinomycetes for antibacterial activity

All the 22 isolates SVNMA1-SVNMA22 were screened for antibacterial activity using agar well diffusion assay against two gram positive (Bacillus subtilis, Staphylococcus aureus) and 
two gram negative bacteria (Escherichia coli, Klebsiella pneumonia).

The screening results showed $27.5 \%$ isolates are active against single bacteria, $59.09 \%$ were active against two bacteria and $4.5 \%$ isolates were active against three bacteria. Among the tested two groups of bacteria gram positive were more sensitive and inhibited by 17 isolates $(81.8 \%)$ and gram negative bacteria were less sensitive and inhibited by 11 isolates $(50 \%)$. However, both gram+ve and gram-ve bacteria were inhibited by 6 isolates (27\%). The zone of inhibition in case of gram+ve bacteria ranges from $1.0 \mathrm{~mm}$ to $15 \mathrm{~mm}$ and in case of gram-ve bacteria ranges from $1.0 \mathrm{~mm}$ to $11 \mathrm{~mm}$. Among the tested gram+ve bacteria Bacillus subtilis is more sensitive than Staphylococcus aureus. $72 \%$ isolates exhibited sensitivity against Bacillus subtilis and 36\% isolates exhibited sensitive against Staphylococcus aureus, 22\% isolates were not active against any two gram+ ve bacteria. Escherichia coliis more sensitive than Klebsiella pneumonia. Escherichia coli is sensitive to $45 \%$ isolates whereas Klebsiella pneumonia is sensitive to 22 isolates. Remaining $50 \%$ isolates were not active against any two gram-ve bacteria(Table-4). Three potential isolates with broad spectrum activity or strong antibacterial activity were selected for further studies. They are SVNMA8, SVNMA11 and SVNMA13. While the screening of the novel secondary metabolites, isolated actinomycetes exhibiting more activity against gram positive bacteria than gram negative bacteria were much encountered. This was similar to the findings of another study (Kokare et al., 2004). Actinomycetes have been confirmed as a potential origin of bioactive compounds and the affluent source of secondary metabolites (Suthindhiran and Kannabiran, 2009). Various media and plating methods were employed for the isolation of actinomycetes, the best one is ISP-2 medium and pour plate method. A total of 22 actinomycetes isolates were isolated and cultural characteristics were studied. Aerialmass of the colonies ranged from whitish ash to dark ash, light brown to dark brown, light pink to dark pink. Riverside pigmentation and soluble pigments were not detected in most of the isolates except SVNMA 2, SVNMA 3 and SVNMA 13. Similarly, melanoid pigmentation was absent in all the isolates except SVNMA 13.All the 22 isolates (SVNMA1- SVNMA 22) were screened for antibacterial activity. Among that, SVNMA8, SVNMA 11 and SVNMA 13 were more potent.

\section{Acknowledgement}

The financial support for this project is funded by Department of Science and Technology, New Delhi under DST-INSPIRE program is gratefully acknowledged.

\section{References}

Abussaud, M. J., Alanagreh, L., Abu-Elteen, K.2013.Isolation, characterization and antimicrobial activity of Streptomyces strains from hot spring areas in the northern part of Jordan. African J Biotech;12(51):7124-7132.

Atta, M.A., and Ahmad, M.S.2009. Antimycin-A antibiotic biosynthesis produced by Streptomyces sp. AZ-AR262: taxonomy, fermentation, purification and biological activities. Australian Journal of Basic Science3:126-135.

Baker, C.N., Stocker, S.A., and Culver, D.H. 1991. Comparison of the E Test to agar dilution, broth micro dilution, and agar diffusion susceptibility testing techniques by using a special challenge set of bacteria. J Clin Microbiol, 29, 533-538.

Berdy, J.2005. Bioactive microbial metabolites, a personal view. $J$. 
Antibiot. 58, 1-26.

Downes F. P., and Ito K. 2001. Compendium of Methods for the Microbiological Examination of Foods, 4th Ed.

Euzeby, J. P.2008. List of prokaryotic names with standing in nomenclature: A folder available on the Internet. Classifications of domains and phyla. USA; p. 590-592.

Hain, T., Ward-Rainey, N., Kroppenstedt, R.M., Stackebrandt, E., Rainey, F.A. 1997. Discrimination of Streptomyces albidoflavus strains based on the size and number of $1623 \mathrm{~s}$ ribosomal DNA intergenic spacers. Int. J. SystBacteriol. 1, 202-206.

Jayapradha Ramakrishnan, Murugesh Shunmuga sundaram, Mahesh Narayanan.2009. Streptomyces sp. SCBT isolated from rhizosphere soil of medicinal plants is antagonistic to pathogenic bacteria. Iranian $\mathbf{J}$ Biotechnol;7(2):75-81.

Kokare, C. R., Mahadik, K. R., Kadam, S. S. 2004. Isolation, characterization and antimicrobial activity of marine halophilic Actinopolyspora species AH1 from the west coast of India. Curr Sci India; 86:593-7.

Krishnan, A., and Kumar, S. S.2015. Optimization of alpha amylase from marine actinomycetes - Streptomyces granidicusASDKT852565. Int Res J Pharm., 6, 10, 729-735.

Kurtboke, D. I., Chen, C. F., and Williams, S. T.1992.Use of polyvalent phage for reduction of streptomycetes on soil dilution plates. J. Appl. Bacteriol. 72, 103-111.

Kuster, E., and williams, S. T. 1964. Selection of media for isolation of streptomycetes. Nature, Lond. 202, 928.

Newman, D. J., Cragg, M. G.2007. Natural products as sources of new drugs over the last 25 years. J Nat Prod 70: 461-
477.

Okami, Y., and Hotta, K. 1988. Search and discovery of new antibiotics in Actinomycetes in Biotechnology, eds M. Goodfellow, S. T. Williams, and M. Mordarski (London: Academic Press), 37-67.

Oskay, M., Tamer A. U. and Azeri C.2004. African J Biotechnol.3 (9).441- 446.

Pandey, B., Ghimire, P., and Agrawal V. P.2004. International Conference on the Great Himalayas: Climate, Health, Ecology, Management and Conservation, Kathmandu, Organized by Kathmandu University and the Aquatic Ecosystem Health and Management Society, Canada.

Rahman, M. A., Islam, M. Z., Khondkar,P., and Islam, M. A. 2010. "Characterization and antimicrobial activities of a polypeptide antibiotic isolated from a new strain of Streptomyces parvulus," Bangladesh Pharmaceutical Journal, vol. 13, no. 1, pp. 14-16.

Saurav, K. and Kannabiran, K.2010. Diversity and Optimization of process parameters for the growth of Streptomyces VITSVK9 spp. isolated from Bay of Bengal, India. J Natural Environ Sci, 1, 2, 56-65.

Shirling, E. B., and Gottlieb, D. 1966. Methods for characterization of Streptomyces sp. Int. J. Syst. Bacteriol. 16, 313-340. 313.

Singh, V., Praveen, V., Banga, J., and Tripathi, C. K. M.2009. Antimicrobial activities of microbial strains isolated from soil of stressed ecological niches of Eastern Uttar Pradesh, India. Indian J. Exp. Biol. 47, 298-303.

Suthindhiran, K., Kannabiran, K.2009. Cytotoxic and antimicrobial potential of actinomycete species Saccharopolyspora salina VITSDK4 isolated from the Bay of Bengal Coast 
of India. Am J Infect Dis;5:90-8.

Takahashi, Y. O., Omura, S. 2003. Isolation of new actinomycete strains for the screening of new bioactive compounds. J Gen Applied Microbiol 49: 141-154.

Takahashi, Y., and Omura, S.2003. Isolation of new actinomycete strains for the screening of new bioactive compounds. J. Gen. Appl. Microbiol. 49, 141-154.

Thombre, R., Joshi, V., andOke, R. 2016.
Halophiles: Pharmaceutical potential and Biotechnological applications. In: Thangadurai D and Jeyabalan S, ed. Industrial Biotechnology: Sustainable Production and Bioresource Utilization. New Jersey, USA: Apple Academic Press Inc, 111- 139.

Waksman, S. A., and Henrici, A. T.1943. The nomenclature and classification of the actinomycetes. Journal of Bacteriology, 46, 337-341.

\section{How to cite this article:}

Gajula Swarna Kumari, Prasada Babu Gundala and Paramageetham Chinthala. 2021. Isolation of Antibiotic Producing Actinomycetes from Saltpans. Int.J.Curr.Microbiol.App.Sci. 10(04): 409-421. doi: https://doi.org/10.20546/ijcmas.2021.1004.044 